\title{
TEPLÁ ASFALTOVÁ SMĚS S POUŽITÍM TECHNOLOGIE PĚNOASFALTU
}

\section{WARM MIX ASPHALT USING TECHNOLOGY OF FOAM BITUMEN}

\author{
Ondřej Machel ${ }^{*}, 1$
}

*ondrej.machel@cdv.cz

${ }^{1}$ Centrum dopravního výzkumu, v. v. i., Divize udržitelné dopravy a diagnostiky dopravních staveb, Líšeňská 2657/33a, 63600 Brno, Česká republika

\begin{abstract}
Abstrakt
V dnešní době je kladen stále větší důraz na ochranu životního prostředí. Tyto nároky se samozřejmě nevyhnuly ani silničnímu stavitelství. Pro výstavbu většiny pozemních komunikací se využívají asfaltové kryty, přičemž př̀i výrobě těchto směsí je potřeba dosáhnout vysokých teplot, což je energeticky náročné a zároveň dochází k zatěžování životního prostředí. Aby se tyto negativní vlivy co nejvíce snížily, rostou snahy o snížení pracovních teplot se zachováním vlastností směsí. Výsledkem jsou tzv. teplé asfaltové směsi (Warm Mix Asphalt - WMA). Cílem tohoto článku je seznámení se základními metodami snižování pracovní teploty s konkrétním zaměřením na technologii pěnoasfaltu a jejím využitím v České republice.
\end{abstract}

Klíčová slova

Asfaltová směs, asfaltové pojivo, asfaltový beton, pěnoasfalt

\begin{abstract}
Nowadays, more and more attention is paid to the environment protection. The issues of the environment protection are obviously related to road engineering as well. Asphalt pavements are used in the majority of road constructions. When producing these mixtures, it's necessary to reach high temperatures, which is energetically demanding and at the same time there are impacts on the environment. In order to reduce the negative effects as much as possible, there are efforts to reduce working temperatures while keeping the properties of the mixtures. The result is the so-called Warm Mix Asphalt - WMA. The aim of this article is to introduce basic methods for reducing working temperatures with a focus on the foam bitumen technology and its use in the Czech Republic.
\end{abstract}

\section{Key words}

Asphalt mixture, asphalt binder, asphalt concrete, foam bitumen

\section{1 ÚVOD}

Silniční doprava zažívá nebývalý nárust, což je dáno řadou výhod, které tento druh dopravy nabízí. S nárustem silniční dopravy je samozřejmě také spojeno rozšiřování silniční sítě. Co se týká konstrukce krytu vozovky, rozlišujeme dva základní druhy: tuhé vozovky, což jsou vozovky s cementobetonovým krytem, a netuhé vozovky, tedy vozovky, jejichž kryt je tvořen některým typem asfaltové směsi. Data z European Asphalt Pavement Association (EAPA) jasně ukazují, že více než 90 \% všech pozemních komunikací v Evropě je postaveno s netuhou vozovkou [1].

Toto je důvod, proč je výstavba pozemních komunikací problémem z hlediska životního prostředí. Asfaltové směsi se vyrábějí na tzv. obalovnách, kde dochází k míchání nahřátého kameniva s asfaltovým pojivem a dalšími přísadami. Tento proces je prováděn při vysokých teplotách, což je hlavním problémem této výroby. S vysokou teplotou se zvyšuje energetická a finanční náročnost výroby a zejména dochází ke zvyšování produkce $\mathrm{CO}_{2}$. Mezi další problémy se řadí zhoršení pracovních podmínek. Následující graf(Obr. 1) názorně ukazuje nárust energetické náročnosti při zvyšování pracovní teploty. 


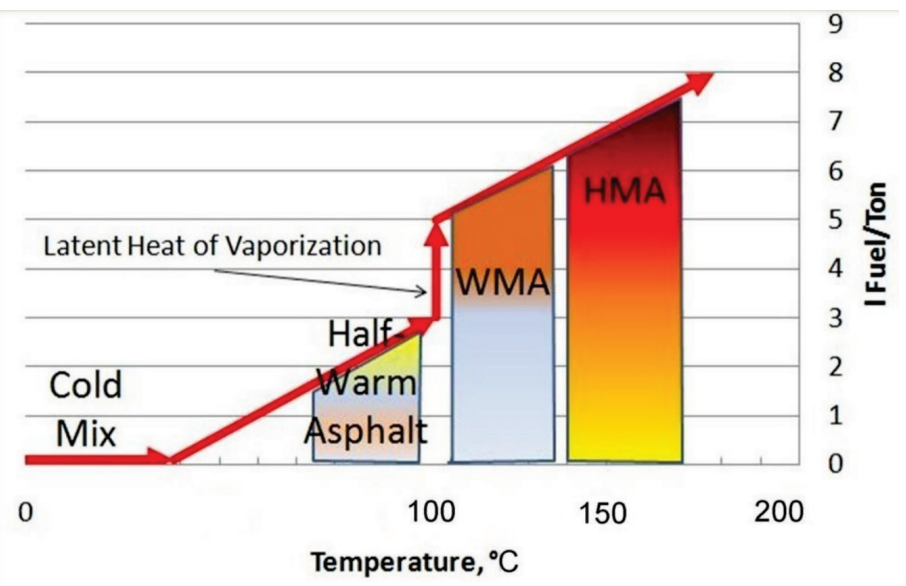

Obr. 1 Závislost pracovní teploty na energetické náročnosti [2].

Dnešní doba se nese v duchu ochrany životního prostředí a snahy snížit negativní vlivy s tím spojené. Co se týče silničního stavitelství, existuje snaha snížit pracovní teplotu a zároveň zachovat funkční vlastnosti asfaltových směsí. Tímto způsobem vzniká tzv. teplá asfaltová směs (Warm Mix Asphalt - WMA). Cílem tohoto článku je seznámit čtenáře se základními způsoby výroby směsí typu WMA s detailnějším zaměřením na technologii pěnoasfaltu. Dále je v tomto článku popsáno, čeho se zatím v této problematice dosáhlo v České republice.

\section{ZPŮSOBY SNÍŽENÍ PRACOVNÍ TEPLOTY}

\section{Základní dělení asfaltových směsí dle pracovní teploty}

Na základě pracovní teploty můžeme rozdělit asfaltové směsi do 4 základních skupin [3]:

- Studená asfaltová směs (Cold Mixes) - pracovní teplota v rozmezí $15-25^{\circ} \mathrm{C}$

- Poloteplá asfaltová směs (Half Warm Asphalt) - pracovní teplota v rozmezí $70-100^{\circ} \mathrm{C}$

- Teplá asfaltová směs (Warm Mix Asphalt) - pracovní teplota v rozmezí $100-150{ }^{\circ} \mathrm{C}$

- Horká asfaltová směs (Hot Mix Asphalt) - pracovní teplota v rozmezí 120-190 C

Dominantní skupinou jsou tzv. horké asfaltové směsi, které můžeme označovat jako standardní. O vysokých teplotách těchto směsí můžeme rovněž hovořit jako o běžných teplotách, při kterých dochází k výrobě asfaltových směsí.

\section{Teplé asfaltové směsi (WMA)}

Jak již bylo uvedeno výše, cílem snižování teploty je vznik tzv. teplých asfaltových směsí. Jedná se o směsi, u kterých je pracovní teplota snížena o 20 až $40{ }^{\circ} \mathrm{C}$ (v závislosti na způsobu snížení teploty). Zároveň je však zajištěno dostatečné ztekucení asfaltového pojiva potřebné pro obalení kameniva a následné dostatečné zhutnění směsi při pokládce.

I přes sníženou teplotu však směsi WMA dosahují stejných vlastností jako horké asfaltové směsi a lze je tedy nahradit. Největší prínos mají směsi WMA v tom, že ačkoliv zde dochází ke snížení teploty pouze o maximálně $40{ }^{\circ} \mathrm{C}$, dochází zde k výraznému poklesu produkce skleníkových plynů (viz. porovnání: Obr. 2). Velkou výhodou v porovnání s horkou asfaltovou směsí je rovněž nižší zestárnutí použitého pojiva, což se může příznivě projevit na životnosti vyrobené směsi.

Snížená pracovní teplota zároveň vede k rychlejšímu ochlazení položené asfaltové směsi, což vede k dřívějšímu otevření uzavřeného úseku.

Snížení pracovní teploty je možné dosáhnout třemi způsoby, a to použitím organických, chemických nebo pěnících prrísad. 


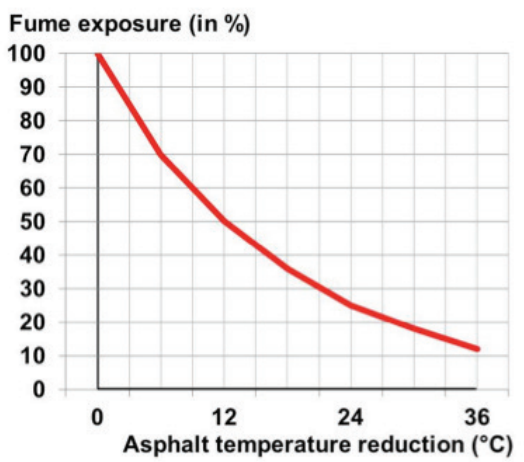

Obr. 2 Vztah mezi produkcí skleníkových plynů a snižováním pracovní teploty [3].

\section{Snižování teploty pomocí organických přísad}

Prvním zpo̊sobem snížení pracovní teploty je použití organických přísad, což jsou přísady na bázi syntetických vosků (montánní vosky a Fischer-Tropschovy parafíny), amidů mastných kyselin, či tenzidy na bázi aminů, které snižují viskozitu asfaltového pojiva. Dávkování probíhá při míchání asfaltové směsi na obalovně nebo přidáním do asfaltového pojiva, čímž vznikne tzv. nízkoviskózní asfaltové pojivo, které se dodává na obalovnu jako hotový výrobek. Ačkoliv je využito nízkoviskózní asfaltové pojivo, je i přesto možné využít při výrobě asfaltové směsi další prrísady. Standardně se pro výrobu využívají tradiční silniční asfalty, polymerem modifikované asfalty, multigrádová asfaltová pojiva nebo tvrdé silniční asfalty [3].

VČeské republice jsou organické přísady pro snížení teploty využívány, detailně tuto problematiku zpracovávají technické podmínky TP 238 - Nízkoteplotní asfaltové směsi [4].

\section{Snižování teploty pomocí chemických přísad}

Další způsob snížení pracovní teploty je přidání chemických přísad, které nesnižují viskozitu asfaltového pojiva, ale upravují povrchové vlastnosti kameniva v mikroskopickém měřítku, což umožňuje prrípravu asfaltové směsi při nižší teplotě.

Mezi chemické přísady se řadí např. Rediset WMX, Zycotherm nebo Evotherm, který je využíván např. v Číně nebo Indii [5], [6].

\section{Snižování teploty pomocí pěnících př́ísad}

Poslední způsob je využití pěnících př́isad zpěňujících asfaltové pojivo. U tohoto způsobu snižování teploty se rozlišují 2 metody [3]:

- Nepř́má metoda

- Př́má metoda - technologie pěnoasfaltu

Co se týká nepř́mé metody, rozlišují se 2 typy. Podstatou prvního typu je využití minerálu jako zdroje vody. Jako takový minerál se využívá např. zeolit, který obsahuje až 20 \% krystalové vody. Pokud dojde k zahřátí zeolitu nad $100{ }^{\circ} \mathrm{C}$, dojde k uvolňování vody, která způsobí zpěnění asfaltového pojiva.

Druhý typ nepř́mé metody je využití vlhkosti písku nebo R-materiálu. Při výrobě asfaltové směsi nejprve obalí asfaltovým pojivem hrubé kamenivo, které tvoří cca 80 \% směsi. Následně se začne dávkovat vlhká jemná frakce kameniva nebo R-materiál, přičemž vlhkost v této frakci začne reagovat s horkým asfaltem. Výsledkem je zpěněné asfaltové pojivo.

Vedle nepřímé metody existuje ještě metoda přímá. Tato metoda je postavená na prrímém dávkování vody ( 1 až $3 \%$ z celkového objemu [7]) do horkého asfaltového pojiva, což rovněž vede k jeho zpěnění. Přímá metoda, tedy technologie pěnoasfaltu, je detailněji popsána v následující kapitole. 


\section{METODA TECHNOLOGIE PĚNOASFALTU}

Jak již bylo výše zmíněno, jedná se o metodu, kdy je pomocí pěnových trysek dávkována voda př́mo do asfaltového pojiva. Tohoto postupu je dosaženo pomocí tzv. zpěňovacího zařízení umístěného na obalovnách. Součástí tohoto zařízení je expanzní komora, kde zpěňování asfaltu probíhá. Nejprve je do komory dávkováno asfaltové pojivo o teplotě $170-190{ }^{\circ} \mathrm{C}$ (využívá se standardní silniční asfalt nebo polymerem modifikované asfaltové pojivo). Následně dojde $\mathrm{k}$ dávkování vody o teplotě $15-25{ }^{\circ} \mathrm{C}$ bez chemických př́sad o objemu uvedeném v předchozí kapitole. Vzhledem k vysoké teplotě asfaltového pojiva dojde ke vzniku vodní páry, což vede $\mathrm{k}$ procesu vzniku asfaltové pěny, tedy materiálu s větším objemem a sníženou viskozitou [8].

Takto vyrobená asfaltová pěna je následně dopravovaná do míchačky obalovny. Zde již dochází ke standardní výrobě, ovšem při nižší pracovní teplotě. Výsledkem je výše zmíněná teplá asfaltová směs, tedy směs typu WMA, která může nahradit standardní horkou asfaltovou směs.

\section{VÝSLEDKY ZKOUŠEK FUNKČNÍCH VLASTNOSTÍ PĚNOASFALTU}

Ačkoliv teplé asfaltové směsi vyrobené technologií pěnoasfaltu dosahují funkčních vlastností srovnatelných s horkou asfaltovou směsí a ve světě je tato technologie využívaná, v České republice tato technologie do nedávna nebyla zakotvena $\mathrm{v}$ žádné normě ČSN a bylo zde realizováno pouze pár staveb se zpěněným asfaltem.

Proto se zde objevila snaha tuto situaci změnit a tuto technologii v České republice prosadit. V letech 2018 až 2020 probíhal výzkumný projekt TAČR: TH03020283 Využití technologie pěnoasfaltu v asfaltových směsích, jehož cílem bylo ověření funkčních vlastností asfaltových směsí s použitou technologií pěnoasfaltu. Na projektu společně spolupracovala Fakulta stavební VUT v Brně a firma COLAS CZ, a. s. V rámci projektu byly provedeny funkční zkoušky asfaltových směsí a empirické a funkční zkoušky extrahovaných asfaltových pojiv [9].

V první fázi došlo k porovnání funkčních vlastností standardních asfaltových směsí a pěnoasfaltových směsí, přičemž zde zatím nebyla využita možnost snižení pracovní teploty. Jako př́ílad je v následujícím grafu (Obr. 3) uvedeno porovnání naměřených výsledkủ standardní směsi ACO 11+ a pěnoasfaltové směsi $\mathrm{ACO} 11+\mathrm{F}$ př̀ měření modulů tuhosti při teplotě $+15^{\circ} \mathrm{C}[10]$.

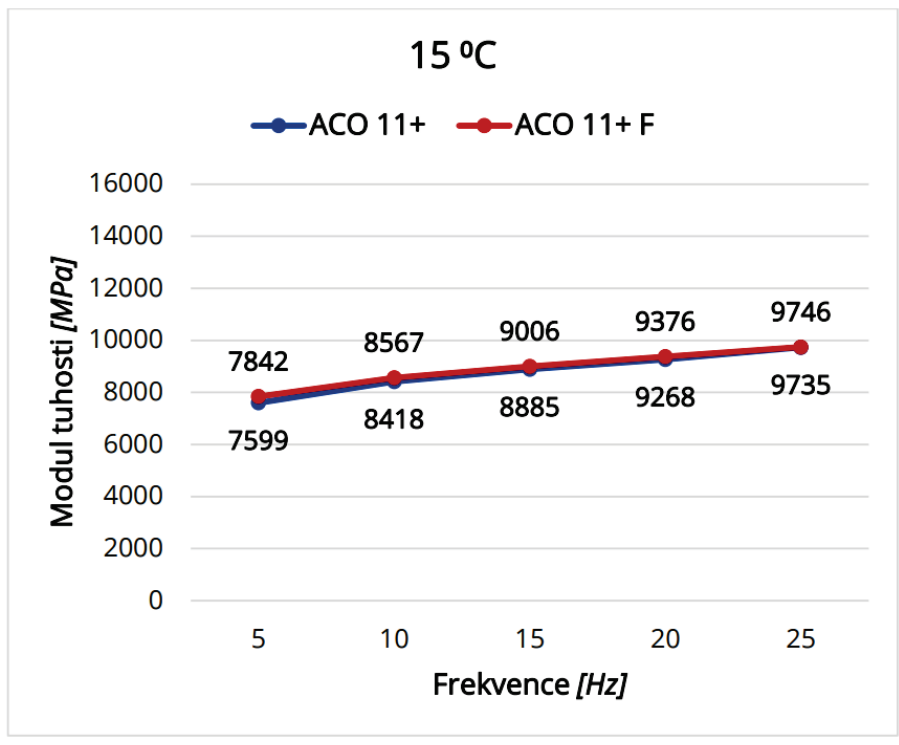

Obr. 3 Výsledné průměrné hodnoty modulů tuhosti při teplotě $+15^{\circ} \mathrm{C}$ u ACO $11+$ a ACO $11+\mathrm{F}[10]$.

Z grafu je patrné, že přidání vody při výrobě směsi nijak výrazně neovlivnilo naměřené hodnoty modulů tuhosti. Podobných výsledků se dosáhlo i při měření za jiných teplot. TP 170 předepisuje pro asfaltové betony AC při teplotě $+15^{\circ} \mathrm{C}$ a frekvenci $10 \mathrm{~Hz}$ minimální hodnotu modulu tuhosti $7500 \mathrm{MPa}$. Naměřené hodnoty dosahují vyšších hodnot, než je v TP 170 požadováno [11]. 
V dalším kroku došlo k porovnávání dalších typů pěnoasfaltových směsí, které byly vyrobeny při různých teplotách. Následující graf (Obr. 4) ukazuje stejné porovnání, byly ovšem porovnávány dvě pěnoasfaltové směsi, a to ACO $11+\mathrm{F}$ vyrobená při teplotě $150{ }^{\circ} \mathrm{C}$ a ACO $11+\mathrm{F}$ vyrobená při teplotě $130{ }^{\circ} \mathrm{C}[12]$.

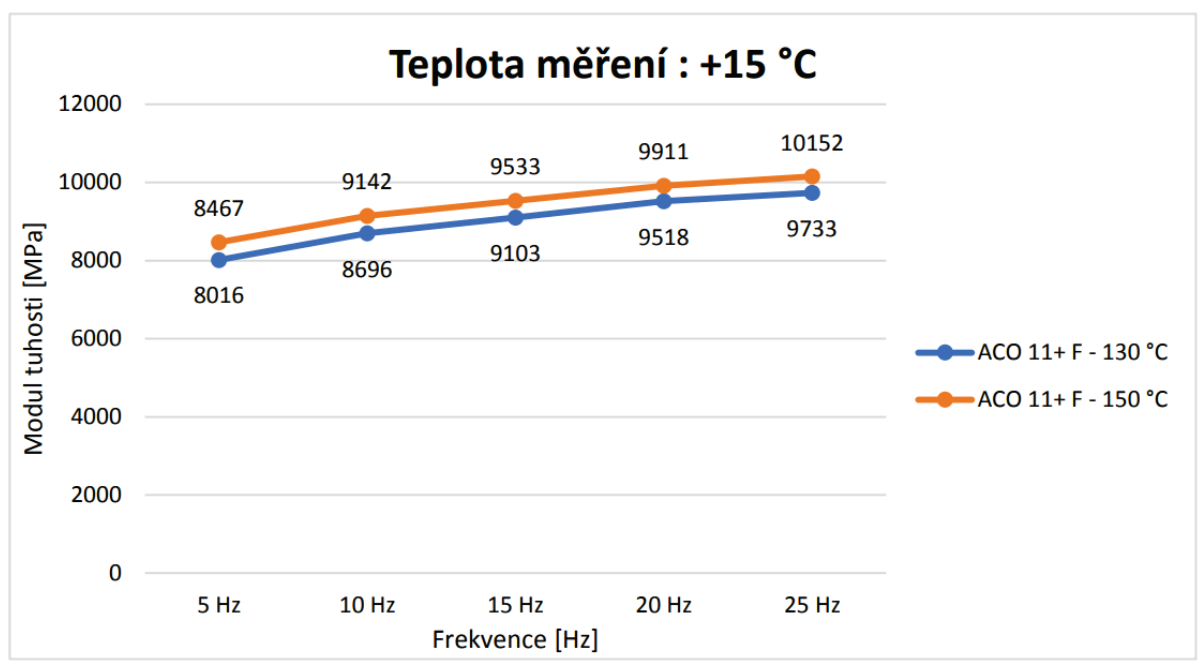

Obr. 4 Výsledné průměrné hodnoty modulů tuhosti při teplotě $+15^{\circ} \mathrm{C} \mathrm{u} \mathrm{ACO} 11+\mathrm{F}-130{ }^{\circ} \mathrm{C}$ a $\mathrm{ACO} 11+\mathrm{F}-150^{\circ} \mathrm{C}[12]$.

Porovnání dokázalo, že při snížení pracovní teploty došlo ke snížení hodnoty modulu tuhosti, což je způsobeno faktem, že při nižší pracovní teplotě dochází k menšímu zestárnutí asfaltového pojiva a tím je směs méně tuhá. Ačkoliv došlo k tomuto jevu, směs dosahuje požadovaných funkčních vlastností a zároveň je možné konstatovat, že menší zestárnutí pojiva se pozitivně projeví na životnosti směsi.

Výzkumný projekt dokázal, že při využití technologie pěnoasfaltu je možné snížit pracovní teplotu a zároveň zachovat požadované funkční vlastnosti. Díky tomuto výsledku se podařilo tuto technologii zakotvit do aktualizované normy ČSN 736120 Ostatní asfaltové směsi - Provádění a kontrola shody [13].

\section{P̌̌EDPISY ZABÝVAJÍCÍ SE SMĚSÍ TYPU WMA A PĚNOASFALTEM V ČESKÉ REPUBLICE}

Prvním předpisem, který zpracovává problematiku teplých asfaltových směsí jsou výše zmíněné TP 238 Nízkoteplotní asfaltové směsi (NTAS) z roku 2012. Tyto TP popisují 3 metody snížení viskozity asfaltového pojiva, a to použití nízkoviskózního asfaltového pojiva s organickými prrísadami, dávkování organické přísady během míchání asfaltové směsi a dávkování minerální př́sady. Takto vyrobené asfaltové směsi je dle TP možné použít do obrusné, ložní i podkladní vrstvy, přičemž je doporučeno tuto směs využít např. při stavbě v tunelech, ve vnitřních prostorách, pro zpevnění ploch s požadavkem na urychlené uvedení do provozu atd. Co se týká technologie pěnoasfaltu, je zde pouze zmíněna jako v zásadě vhodná metoda, ale dále není tato metoda rozpracována [4].

Jak bylo zmíněno v předchozí kapitole, výsledkem výzkumného projektu TAČR bylo zařazení technologie pěnoasfaltu do normy ČSN 736120 Ostatní asfaltové směsi - Provádění a kontrola shody, konkrétně v př́loze I Požadavky na nízkoteplotní směsi. Tato prŕloha definuje nízkoteplotní směs, jakožto směs, která se vyrábí a rozprostírá při teplotě nad $120^{\circ} \mathrm{C}$ a kde je doloženo, že došlo ke snížení pracovní teploty minimálně o $15^{\circ} \mathrm{C}$. Př́loha se dotýká jak materiálů popsaných v TP 238, tak právě technologie pěnoasfaltu, která se dá dle normy použít jak při výrobě nízkoteplotní asfaltové směsi, tak při výrobě standardní směsi v souladu s normou ČSN 73 6121, kde není využit potenciál snížení teploty, je zde ovšem možnost dopravit vyrobenou směs na větší vzdálenosti [13], [14].

U nízkoteplotní asfaltové směsi se v případě použití nízkoviskózního asfaltového pojiva používá písemný znak "NV", který se umist’uje za označení asfaltové směsi. Pokud se přímo při výrobě použije vhodná přísada, užívá se písemný znak "NT". Při využití technologie pěnoasfaltu se využívá písemný znak "NT-ZA". Norma ČSN 736120 uvádí následující příklad: Vrstva asfaltového betonu pro ložní vrstvu s velikostí oka horního síta nejhrubší použité 
frakce kameniva $16 \mathrm{~mm}$, se zpěněným asfaltovým pojivem 50/70, tloušt'ka vrstvy $60 \mathrm{~mm}$, odpovídající normě pro specifikaci se označí: ACL 16 NT-ZA 50/70; 60 mm; ČSN 736121 [4], [13].

Technologie pěnoasfaltu ovšem byla v České republice zpracována již dřive. V roce 2007 byly vydány TP 112 - Studené pěnoasfaltové vrstvy, které se zabývají výrobou a využitím tzv. studené pěnoasfaltové směsi (PAS). Tato směs se vyrábí tak, že se do pěnícího zařízení k asfaltovému pojivu o teplotě $160-170{ }^{\circ} \mathrm{C}$ dávkuje studená voda v množství 1 až 5 \%. Vzniklá asfaltová pěna se použije k obalení vlhkého kameniva. Jedná se ovšem o studenou směs, která nemůže díky svým vlastnostem nahradit horkou asfaltovou směs [15].

\section{ZÁVĚR}

Cílem článku bylo seznámení s problematikou teplých asfaltových směsí (WMA) s konkrétním zaměřením na př́mou metodu dávkování vody, tedy technologii pěnoasfaltu. Obavy z této v České republice nové technologie jsou pochopitelné, zejména obava z neúplného odpaření dávkované vody při výrobě zpěněného asfaltu, která může následně mít negativní vliv na výslednou směs. Výše zmíněné zkoumání ovšem dokázalo, že k tomuto problému nedochází a vyrobená směs se kvalitou shoduje se standardní horkou asfaltovou směsí.

Pěnoasfalt je velmi praktická technologie, která umožňuje snížení pracovní teploty, což zajistí snížení produkce $\mathrm{CO}_{2}$ a celkově snížení energetické a finanční náročnosti výroby. Zároveň je možné s pomocí této technologie dopravit směs vyrobenou při standardní pracovní teplotě na větší vzdálenost.

Díky těmto výhodám je vhodné tuto technologii využívat v co největší možné míře v praxi.

\section{Poděkování}

Tento článek byl vytvořen za finanční podpory Ministerstva dopravy v rámci programu dlouhodobého koncepčního rozvoje výzkumných organizací.

\section{Použité zdroje}

[1] EAPA [online]. [cit. 2021-10-25]. Dostupné z: https://eapa.org/recycling

[2] EAPA [online]. [cit. 2021-11-28]. Dostupné z: https://www.asfaltblij.nl/media/1416/2009june-the-use-ofwarm-mix-asphalt.pdf

[3] EAPA [online]. [cit. 2021-10-25]. Dostupné z: https://eapa.org/warm-mix-asphalt

[4] TP 238 - Nízkoteplotní asfaltové směsi (NTAS), MINISTERSTVO DOPRAVY ČR, 2011

[5] MASTNÝ, Jan, Vliv syntetických vosků a rejuvenátorů na vlastnosti asfaltové směsi s R-materiálem. Praha, 2017. 78 s., 27 s. příl. Diplomová práce. České vysoké učení technické v Praze, Fakulta stavební, Katedra silničních staveb. Vedoucí práce Ing. Jan Valentin, Ph.D.

[6] KUMAR, Rajiv, CHANDRA, Satish. Warm mix asphalt investigation on public roads - A review. India, 2016. 12 s. Indian Institute of Technology - Roorkee, Department of Civil Engineering.

[7] DUPUY, Jean Paul, CARBONNEAU, Xavier. Pěnoasfaltové směsi. In: asfaltové-vozovky.cz [online]. [cit. 2021-10-25]. Dostupné z: http://www.asfaltove-vozovky.cz/av2017/data/prezentace/t18 dupuy.pdf

[8] HÝZL, Petr, DAŠEK, Ondřej. Rešerše na stav techniky pro využití technologie pěnoasfaltu při výrobě asfaltových směsí za horka. Brno, 2017 Vysoké učení technické v Brně, Fakulta stavební, Ústav pozemních komunikací

[9] Využití technologie pěnoasfaltu v asfaltových směsích. Technologická agentura České republiky [online]. [cit. 2021-10-25]. Dostupné z: https://starfos.tacr.cz/cs/project/TH03020283

[10] VENCLÍKOVÁ, Michaela. Využití pěnoasfaltu v asfaltových směsích. Brno, 2018. 93 s., 20 s. příl. Diplomová práce. Vysoké učení technické v Brně, Fakulta stavební, Ústav pozemních komunikací. Vedoucí práce Ing. Petr Hýzl, Ph.D.

[11] TP 170 - Navrhování vozovek pozemních komunikací, MINISTERSTVO DOPRAVY ČR, 2004

[12] MACHEL, Ondřej. Využití technologie pěnoasfaltu. Brno, 2019. 93 s., 41 s. příl. Diplomová práce. Vysoké učení technické v Brně, Fakulta stavební, Ústav pozemních komunikací. Vedoucí práce Ing. Petr Hýzl, Ph.D.

[13] ČSN 736120 Stavba vozovek - Ostatní asfaltové směsi - Provádění a kontrola shody, Úřad pro technickou normalizaci, metrologii a státní zkušebnictví, 2021

[14] ČSN 736121 Stavba vozovek - Hutněné asfaltové vrstvy - Provádění a kontrola shody, Úřad pro technickou normalizaci, metrologii a státní zkušebnictví, 2019

[15] TP 112 - Studené pěnoasfaltové vrstvy, MINISTERSTVO DOPRAVY ČR, 2007 